\title{
Spatial distribution of air temperature in central part of Svalbard in the period 2008-2010
}

\author{
Denisa Witoszová*, Kamil Láska
}

Department of Geography, Faculty of Science, Masaryk University, Kotlářská 2, 61137 Brno, Czech Republic

\section{Short Communication}

\begin{abstract}
The air temperature and wind speed measurements done in the Petunia Bay and Svalbard Lufthaven, in the period from August 2008 to June 2010, were analyzed and related to the differences in weather conditions and their synoptic origins over the central part of Svalbard archipelago. The highest air temperature differences between the two study sites ranged from 3 to $6.8^{\circ} \mathrm{C}$ and occurred most frequently during anticyclonic circulation from January to March. The smallest air temperature differences (from 0 to $2.0^{\circ} \mathrm{C}$ ) appeared from May to October. During advection of air from northern and eastern sectors, the higher air temperature and wind speed occurred at the Petunia Bay than at Svalbard Lufthaven.
\end{abstract}

Key words: Climate, air temperature, synoptic situations, Svalbard

\section{Introduction}

In the Atlantic sector of the Arctic, where the Svalbard archipelago is situated, the atmospheric circulation has a decisive influence on the climate and air temperature field in particular (Niedźwiedź 2007). The influence of atmospheric circulation on air temperature field is most significant during a winter season when there is almost no solar energy yield, but severe energy loss appear due to long wave radiation energy flux from a ground.
The intense and substantial energy lost is mainly compensated by heat advection from lower (middle) latitudes (Przybylak 1992).

The significant changes in air temperature occur especially in winter season which has been reported by many authors (e.g. Brázdil 1988, Hanssen-Bauer et Førland 1998, Przybylak 2000, Tuomenvirta et al. 2000). These studies focused mainly on the relationship be-

Received October 28, 2012, accepted December 17, 2012.

${ }^{*}$ Corresponding author: dratenicek@centrum.cz

Acknowledgements: This study was supported by the project LM2010009 CzechPolar (MSMT CR), and project of the EHP No. B/CZ0046/3/0013 "Effects of climate change on tundra ecosystem: Interaction of vegetation with extreme environments". The work of Denisa Witoszová was supported by the project of Masaryk University (MUNI/A/0966/2009) "Expression of Global Environmental Change in Component Earth's Spheres" (PROGLEZ). 
tween atmospheric circulation and distribution of air temperature in the Atlantic sector of the Arctic. However, air temperature distribution over the Svalbard archipelago is related rather to the degree of climate continentality than to its latitude. Recently, the influence of heat advection from lower latitudes in the central part of Svalbard during polar night was investigated by Bednorz et Fortuniak (2011). This phenomenon of a semi-annual

\section{Material and Methods}

The main goal of our study was to evaluate spatiotemporal variability of air temperature in the central part of Spitsbergen, the largest island of Svalbard archipelago. Another goal was to analyse the influence of synoptic situations on air temperature and wind speed differences between the below-specified two sites located inside the Isfjorden, the second longest fjord in Svalbard. The attention was focused on two localities - the Petunia Bay $\left(78^{\circ} 42.11^{\prime} \mathrm{N}, \quad 16^{\circ} 27.64^{\prime} \mathrm{E}\right)$, and Svalbard Lufthavn station $\left(78^{\circ} 14.75^{\prime} \mathrm{N}\right.$, $\left.15^{\circ} 27.93^{\prime} \mathrm{E}\right)$. The first study site was located at an altitude of $15 \mathrm{~m}$ a.s.l. on the coastal ice-free zone of the Petunia Bay, northern branch of Billefjorden (Isfjorden). The automatic weather station (AWS) was situated approximately $500 \mathrm{~m}$ from the coastline and equipped with a set of sensors for the measurements of air temperature and relative humidity at a height of $2 \mathrm{~m}$, air pressure, global and reflected shortwave radiations, photosynthetically active radiation, air pressure, wind speed and direction at a height of

\section{Results and Discussion}

In this study, hourly, daily and monthly means and extremes of air temperature and wind speed were analyzed in the period temperature cycle is called "coreless" winter during which the lack of cold core occurs due to the long-term warm period. Nevertheless, the local topography and sea ice conditions play an essential role in modifying both airflow structure and local climate conditions of the central part of the Svalbard archipelago (Láska et al. 2012). In this study, we analyze the role of synoptic situations in air temperature spatial distribution.

$6 \mathrm{~m}$, surface temperature of tundra vegetation, soil temperature profile measured to the depth of $150 \mathrm{~cm}$ (for instrumental set up see Láska et al. 2012).

The second site was situated at the beginning of Adventfjorden, $4.8 \mathrm{~km}$ northwest of Longyearbyen at an altitude of $28 \mathrm{~m}$ a.s.l. The distance between Svalbard Lufthavn station and the Petunia Bay is $56 \mathrm{~km}$. The meteorological data for Svalbard Lufthavn were provided by the Norwegian Meteorological Institute in Oslo (web page: http://eklima.met.no). The assessment of atmospheric circulation pattern and air temperature differences between both sites was made by means of circulation types provided by Niedźwiedź (2012). The circulation types were classified according to surface pressure field and direction of the geostrophic wind. The author of the classification distinguished 21 circulation types according to common directions of advection, adding the symbol ' $a$ ' for anticyclonic (high pressure) and 'c' for cyclonic (low pressure) systems.

from August $1^{\text {st }}, 2008$ to June 30 ${ }^{\text {th }}, 2010$. Mean air temperature at the Petunia Bay was $-5.1^{\circ} \mathrm{C}$, while it reached $-3.3^{\circ} \mathrm{C}$ at 
Svalbard Lufthavn. Summer temperatures (June-August) varied from $-2^{\circ} \mathrm{C}$ to $+12^{\circ} \mathrm{C}$ in the Petunia Bay and from $0^{\circ} \mathrm{C}$ to $+11^{\circ} \mathrm{C}$ at Svalbard Lufthavn. The winter temperatures (December-February) ranged from $+3^{\circ} \mathrm{C}$ to $-30^{\circ} \mathrm{C}$ in the Petunia Bay, while they ranged from $+4^{\circ} \mathrm{C}$ to $-28^{\circ} \mathrm{C}$ at Svalbard Lufthavn. The absolute minimum air temperature of $-33.3^{\circ} \mathrm{C}$ was recorded on 12 January 2009 in the Petunia Bay, while it reached $-31.6^{\circ} \mathrm{C}$ at Svalbard Lufthavn on 7 January 2009. In July 2009, the maximum air temperature reached the value of $16.2^{\circ} \mathrm{C}$ in the Petunia Bay and $12.1^{\circ} \mathrm{C}$ at Svalbard Lufthavn. Such high values were reached due to sunny weather and only a light breeze with wind speed below $2 \mathrm{~m} \mathrm{~s}^{-1}$.

Large interdiurnal variability of air temperature (more than $10^{\circ} \mathrm{C}$ day $^{-1}$ ) was found in both locations during winter and spring due to fast changes in air masses advection from different directions (geographical areas). This feature was reflected in standard deviation of air temperature. Generally, summer temperature was much less variable (standard deviation close to $1^{\circ} \mathrm{C}$ ) than winter temperature (standard deviation around $3{ }^{\circ} \mathrm{C}$ ). Similar findings showing small summer temperature variation (standard deviation close to $1^{\circ} \mathrm{C}$ ) and the higher winter temperature variation (standard deviation ranging from $4^{\circ} \mathrm{C}$ to $5^{\circ} \mathrm{C}$ ) were found for Svalbard Lufthavn station by Bednorz et Fortuniak (2011).

In order to evaluate the effect of atmospheric circulation on air temperature, the classification of circulation pattern provided by Niedźwiedź $(2007,2012)$ for the Svalbard archipelago was used in this study. In the period of 2008-2010, prevailing cyclonic activity was found in $58.9 \%$ of the days, while the anticyclonic situations occurred in only $38.1 \%$. The most common circulation types belonged to the north-eastern sector, with a frequency of occurrence of $9.6 \%$ (Ec type), $9.0 \%$ (Nc type), $8.3 \%$ (SEc type) and $7.2 \%$ (NEc type). Considerably high frequencies were found also for the anticyclonic wedge ( $\mathrm{Ka}$ type $-9.0 \%$ ), trough of low pressure (Bc type $-8.6 \%$ ), and anticyclonic situations from the northeastern sector: Na type (5.7\%), NEa type $(5.3 \%)$, and Ea type (6.3\%). The highest frequency of the cyclonic circulation was found in autumn (88.2\%) and winter $(86.6 \%)$. Contrastingly, the anticyclonic types were most common in summer (35.3\%) and spring (19.0\%). A similar pattern was found by Przybylak (1992) on western coast of the Spitsbergen Island in 1979-1983.

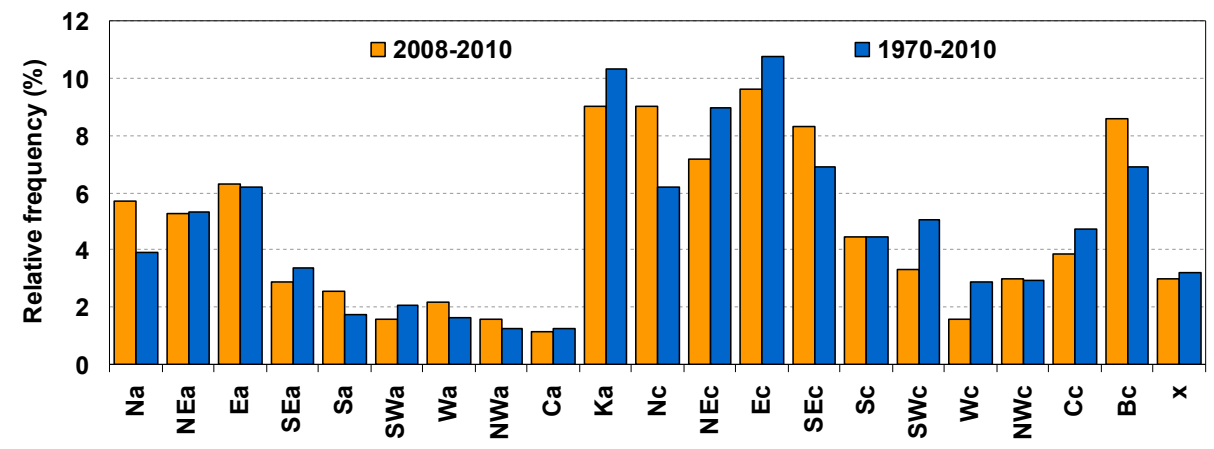

Fig. 1. Relative frequencies of circulation types over Spitsbergen area in the period from August 2008 to June 2010 (orange columns), as compared with the long-term average of the period from 1970 to 2010 (blue columns) - adopted from Láska et. al (2012). 
Mean air temperature difference of $-0.9^{\circ} \mathrm{C}$ found between the Petunia Bay and Svalbard Lufthavn corresponded to the specific thermal regime of the Petunia Bay, which is situated on the northern most branch of Billefjorden and the interior leeward part of the Spitsbergen Island. In the study period, positive differences (higher temperatures in the Petunia Bay than at Svalbard Lufthavn) appeared during the north-eastern cyclonic types with the frequencies of $14.0 \%$ (Ec type), $11.1 \%$ (NEc type) and during the anticyclonic situation with $13.0 \%$ (anticyclonic wedge - Ka type). The negative thermal differences (higher temperatures at Svalbard Lufthavn than in the Petunia Bay) appeared mainly during the cyclonic situations - 10.4\% (Nc type), SEc (8.3\%), $\mathrm{Ec}(7.7 \%)$ and $\mathrm{Bc}(9.6 \%)$.

The highest positive differences $\left(+6.3^{\circ} \mathrm{C}\right.$ at Ec type) occurred on March $24^{\text {th }}, 2009$ and $\left(+6^{\circ} \mathrm{C}\right.$ at $\mathrm{NEa}$ type $)$ on January $2^{\text {nd }}, 2009$, while the highest negative differences were recorded on January $12^{\text {th }}, 2010\left(-6.8^{\circ} \mathrm{C}\right.$ at NWa type $)$ and from
January $12^{\text {th }}$ to $15^{\text {th }}, 2009\left(-6.7^{\circ} \mathrm{C}\right.$ at NWc type). Negative temperature differences were mostly related to the prolongation of the period with permanent snow cover and sea ice presence in the Petunia Bay, and/or suppressed air flow deep inside the Isfjorden and Billefjorden, respectively. From the above facts, it follows that the highest air temperature differences occurred most frequently from January to March, less often in December and/or April. Oppositely, the smallest air temperature differences (from 0 to $2.0^{\circ} \mathrm{C}$ ) appeared from May to October. Similar findings were reported by Przybylak (1992) for four meteorological stations located on western coast of Spitsbergen. However, the differences calculated by Przybylak (1992) reached only the values not higher than $1.5^{\circ} \mathrm{C}$ in summer. Our results showed much higher values of the differences. This may be caused by the fact that the AWS located on western coast are much more influenced by maritime weather conditions than those situated in the Isfjorden, the Petunia Bay in particular.

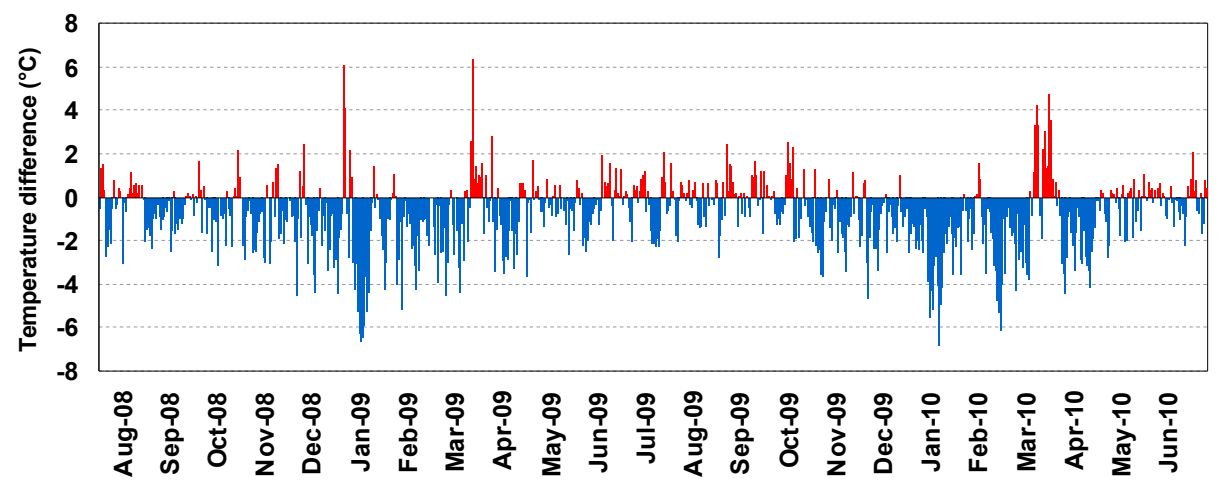

Fig. 2. Fluctuation of daily mean temperature differences between the Petunia Bay and Svalbard Lufthaven stations in the period from August 2008 to June 2010. Positive difference means a higher air temperature reached in the Petunia Bay than at Svalbard Lufthaven and vice versa. 
The wind speed differences between both sites were examined for the period from July 2009 to June 2010. The effect of atmospheric circulation on the surface wind speed was studied by means of the circulation types, positive and negative differences of wind speed. We found that more than $50 \%$ of positive differences (higher wind speed in the Petunia Bay than at Svalbard Lufthavn) were related to the north-eastern cyclonic situations represented by the circulation types $\mathrm{Nc}$
(21.1\%), NEc (20.2\%), and Ec (7.3\%). The negative differences (higher wind speed at Svalbard Lufthavn than in the Petunia Bay) appeared mostly during the cyclonic types SEc (12.9\%), Ec (9.2\%), and $\mathrm{Bc}(8.8 \%)$. The highest positive difference $\left(+7.5 \mathrm{~m} \mathrm{~s}^{-1}\right)$ was recorded on March $29^{\text {th }}, 2010$ during NEa advection, while the highest negative difference $\left(-10.3 \mathrm{~m} \mathrm{~s}^{-1}\right)$ occurred on October $22^{\text {nd }}$, 2009 at $\mathrm{Wc}$ advection.

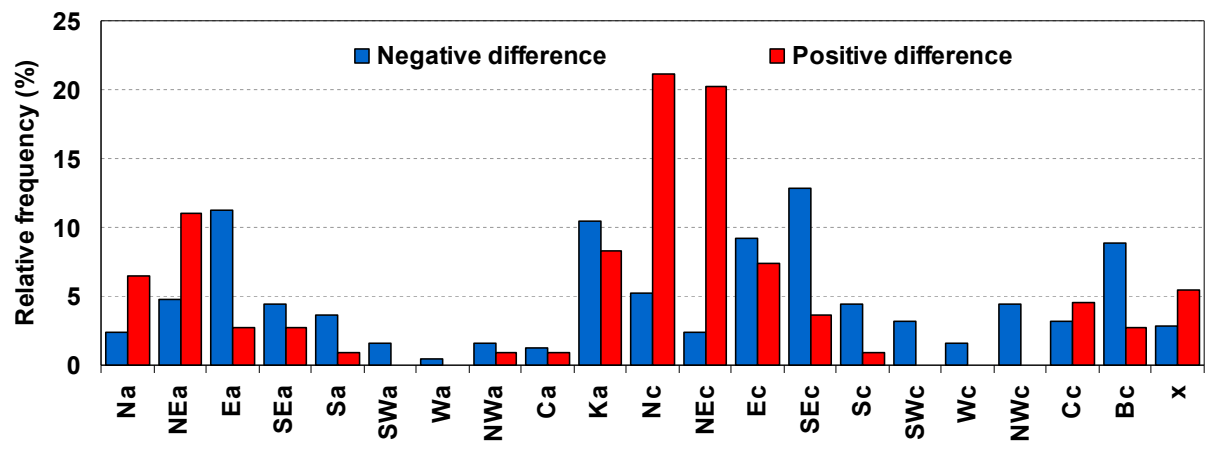

Fig. 3. Relative frequencies of daily mean wind speed differences between the Petunia Bay and Svalbard Lufthaven stations classified according to the circulation types in the period from July 2009 to June 2010. Positive difference (red columns) means higher wind speed in the Petunia Bay than at Svalbard Lufthaven and vice versa.

\section{Conclusions}

We found that air temperature and wind speed slightly differed between the coastal zone of the Petunia Bay and the middle part of Isfjorden, Svalbard Lufthaven in particular. Different thermal regime between both sites was mainly related to the pattern of atmospheric circulation over the area of Spitsbergen and suppressed air flow inside the Isfjorden, Billefjorden, and the Petunia Bay. In the study site in the Petunia Bay, the highest air temperature differences occurred most frequently during anticyclonic circulation from January to March, less often in December and/or April. The smallest air temperature differences (from 0 to $2.0^{\circ} \mathrm{C}$ ) appeared from May to October. Except of mesoscale variability of circulation pattern, local factors, such as snow cover distribution and sea ice extent in the fjords during winter and spring months may affect air temperature and wind speed differences between the middle and terminal part (the Petunia Bay) of the Isfjorden. 


\section{References}

BEDNORZ, E., FORTUNIAK, K. (2011): The occurrence of coreless winters in central Spitsbergen and their synoptic conditions. Polar Research, 30: 122-132.

BRÁZDIL, R. (1988): Variation of air temperature and atmospheric precipitation in the region of Svalbard. In: R. Brázdil (eds.) Results of Investigations of the Geographical Research Expedition Spitsbergen 1985. J.E. Purkyně University, Brno: 187-210.

BrÜmmer, B., ThiEMAnN, S. and KIRChäßNER, A. (2000): A cyclone statistics for the Arctic based on European Centre re-analysis data. Meteorology and Atmospheric Physics, 75: 233-250.

HANSSEN-BAUER, I., FøRLAND E.J. (1998): Long-term trends in precipitation and temperature in the Norwegian Arctic: can they be explained by changes in atmospheric circulation patterns? Climate Research, 10: 143-153.

Hanssen-Bauer, I., SolÅs, M.K. and Stefensen, E.L. (1990): The Climate of Spitsbergen. DNMI Rep. 39/90 Klima: 40 pp.

LÁska, K., WitoszovÁ, D. and ProšEK, P. (2012): Weather patterns of the coastal zone of Petuniabukta, central Spitsbergen in the period 2008-2010. Polish Polar Research, 33: 297 318.

Niedźwiedź, T. (2007): Atmospheric circulation. In: A. Marsz and A. Styszyńska (eds.): The climate of area of the Polish Polar Hornsund Station. Wydawnictwo Akademii Morskiej w Gdyni: 45-64 (in Polish).

NiEDźWIEDŹ, T. (2012): The calendar of atmospheric circulation types for Spitsbergen. A computer file (http://klimat.wnoz.us.edu.pl/osoby/tn/Spitsbergen.zip), University of Silesia, Department of Climatology, Sosnowiec, Poland.

PRZYBYLAK, R. (1992): Spatial differentiation of air temperature and relative humidity on the western coast of Spitsbergen in 1979-1983. Polish Polar Research, 13: 113-130.

PRZYBYLAK, R. (2000): Temporal and spatial variation of surface air temperature over the period of instrumental observations in the Arctic. International Journal of Climatology, 20: 587-614.

Tuomenvirta, H., Alexandersson, H., Drebs, A., Frich, P. and Nordli, P.Ø. (2000): Trends in Nordic and Arctic temperature extremes and ranges. Journal of Climate, 13: 977-990. 